\title{
Effects of Fractionated Neem Leaf Extract (IRC) on Blood Glucose Level in Alloxan Induced Diabetic Wistar Rats
}

\section{Okpe Aaron $\mathrm{C}^{1}$, Nwadike Kenneth $\mathrm{I}^{*}$, Uwaezuoke Nkemjika $\mathrm{JI}^{1}$, Eze Oliver $\mathrm{U}^{1}$, Anieze Chisom $\mathrm{E}^{2}$, Nwoke Obinna $C^{1}$, Ali George $U^{1}$, Shu Elvis $N^{1}$ and Udeinya Iroka $J^{1}$}

${ }^{1}$ Department of Pharmacology and Therapeutics, College of Medicine, University of Nigeria, Enugu campus, Nigeria

${ }^{2}$ Department of Chemical Pathology, College of Medicine, University of Nigeria, Enugu campus, Nigeria

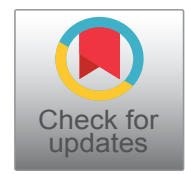

*Corresponding author: Nwadike kenneth I, Department of Pharmacology/Therapeutics, College of Medicine, University of Nigeria Enugu Campus, Nigeria

\begin{abstract}
This study evaluated the hypoglycaemic effects of fractionated neem leaf extract (IRC) on alloxan induced diabetic wistar rats. IRC dissolved in phosphate buffered saline (PBS) PH 7.2 was administered as $50 \mathrm{mg} / \mathrm{kg}, 500$ $\mathrm{mg} / \mathrm{kg}, 1000 \mathrm{mg} / \mathrm{kg}, 2000 \mathrm{mg} / \mathrm{kg}$ single doses and $5 \mathrm{mg} /$ $\mathrm{kg}, 50 \mathrm{mg} / \mathrm{kg}, 250 \mathrm{mg} / \mathrm{kg}$ and $500 \mathrm{mg} / \mathrm{kg}$ repeated doses in the diabetic rats while in the normoglycaemic rats 100 $\mathrm{mg} / \mathrm{kg}$ and $250 \mathrm{mg} / \mathrm{kg}$ were used respectively. The positive control groups received single and repeated doses of glibenclamide $(5 \mathrm{mg} / \mathrm{kg}$ ) while the negative control groups were left untreated in each case. Single doses of the extract in diabetic wistar rats produced maximal dose dependent percentage reduction after 4 hours of administration with percentage reductions of $13.10 \%$ (500 mg/kg), $14.40 \%$ $(1000 \mathrm{mg} / \mathrm{kg})$ and $17.50 \%(2000 \mathrm{mg} / \mathrm{kg})$ respectively. The result shows that $500 \mathrm{mg} / \mathrm{kg}$ repeated doses gave the highest percentage reduction in fasting blood glucose in alloxan induced diabetic rats after 7, 14 and 21 days as follows $55 \%, 31.7 \%$ and $29.3 \%$ while $250 \mathrm{mg} / \mathrm{kg}$ repeated doses produced the highest percentage reduction of fasting blood glucose in non-diabetic rats at 7, 14 and 21 days and are $21.4 \%, 26.6 \%, 25.16 \%$ respectively. In conclusion, IRC lowered fasting blood glucose levels in non-diabetic and alloxan induced diabetic rats when given orally.
\end{abstract}

\section{Keywords}

Glucose, Diabetes, Wistar rat, Irc, Glibenclamide

\section{Introduction}

Nigeria has one of the oldest, richest and diverse cultural traditions associated with the use of herbs in the treatment of human diseases. Traditional medicine is an act of using plant leaves, barks, roots or any other part in the crude form for the treatment of various diseases [1]. A vast ethnobotanical knowledge exists in Nigeria from ancient times and medicinal plants continue to be an important therapeutic aid for alleviating ailments of humankind. Over the last 2500 years, there have been very strong traditional systems of medicine such as Chinese, Ayurvedic, and the Unani, born and practiced, more in the eastern continent. These traditions are still flourishing, since; approximately $80 \%$ of the people in the developing countries rely on these systems of medicine for their primary health care needs [2]. These plants contain substances that can be used for therapeutic purposes, of which are precursors for the synthesis of drugs [3].

Of interest is Azadirachta indica known as neem in many countries of the world. It is a large evergreen tree that belongs to the family Meliaceae. It is believed to have originated from Assam and Burma in south Asia [4] and grow well in tropical and sub-tropical regions around the world [5] with ability to withstand many adverse environmental conditions such as drought, infertile soil, stony, shallow or acidic soil [5].

However, The chemical constituents contain many biologically active compounds that can be extracted from neem, including alkaloids, lavonoids, triterpenoids, phenolic compounds, carotenoids, steroids and ketones, biologically most active compound is azadirachtin, it is actually a mixture of seven isomeric com-

Citation: Okpe AC, Shu EN, Nwadike KI, Udeinya IJ, Nubila NI, et al. (2019) Effects of Fractionated Neem Leaf Extract (IRC) on Blood Glucose Level in Alloxan Induced Diabetic Wistar Rats. Int J Diabetes Clin Res 6:105. doi.org/10.23937/2377-3634/1410105

Accepted: April 02, 2019: Published: April 04, 2019

Copyright: (c) 2019 Okpe AC, et al. This is an open-access article distributed under the terms of the Creative Commons Attribution License, which permits unrestricted use, distribution, and reproduction in any medium, provided the original author and source are credited. 
pounds labelled as azadirachtin A-G and azadirachtin E is more effective [6]. Also, biologically active principles isolated from other parts of the plant include: meliacin, gedunin, nimbidin, nimbolides, salanin, nimbin, valassin. Meliacin forms the bitter principles of Neem oil, the seed contain tignic acid responsible for the distinctive odour of the oil [7]. Neem kernels contain $30-50 \%$ of oil mainly used by the soap, pesticide and pharmaceutical industries and contain many active ingredients which are together called triterpene or limnoids [8]. The four best limnoids compounds are: Azadirachtin Salannin, Meliantriol, and Nimbin. Limonoids contain insecticidal and pesticidal activity [9].

Moreover, Azadirachta indica is used for a wide range of purposes. The oil extracted from the seed (Neem oil) has insecticidal properties $[5,10]$. Neem cake, the residue of neem seed after oil extraction is used as fertilizer $[5,10]$ and also nematicide used to lower soil nitrogen. Neem can treat many skin disorders, including scabies and lice; in a paste combination with Curcuma longa (turmeric), neem was used to treat scabies in 814 people- $97 \%$ of them were cured within 3 to 15 days of application, and no adverse reactions were observed [11]. It is used Pharmacologically as abortifacient, analgesic, antihelminthic, antibacterial, antiyeast, antiulcer, antifertility, antifilarial, antifungal, antihyperglycemic, anti-inflammatory, antiviral, antimalarial, diuretic, antinematodal, antipyretic, antispasmodic, insecticidal, antispermatogenic, antitumor, hypercholesteremic, hypoglycaemic, immunomodulator [12,13]. Recent studies on hypoglycemic action of Azadirachta indica was carried out in diabetic rats. After treatment for 24 $\mathrm{hrs}$, Azadirachta indica $250 \mathrm{mg} / \mathrm{kg}$ (single dose study) reduced glucose $(18 \%)$, cholesterol $(15 \%)$, triglycerides $(32 \%)$, urea $(13 \%)$, creatinine $(23 \%)$, and lipids $(15 \%)$ [14]. Multiple dose study for 15 days also reduced creatinine, urea, lipids, triglycerides and glucose. In a glucose tolerance test in diabetic rats with neem extract $250 \mathrm{mg} / \mathrm{kg}$ demonstrated glucose levels that were significantly less compared to the control group. Azadirachta indica significantly reduced glucose levels after 15 days oral administration in diabetic rats [14]. In HIV/AIDS patients, a 12-week oral administration of acetone water neem leaf extract called IRAB had a significant influence in vivo on $\mathrm{CD} 4$ cells (which HIV reduces) without any adverse effects on the patients. IRAB is 50:50 acetone water neem leaf fractionated extract [15]. Of the 60 patients who completed treatment, 50 were completely laboratory-test compliant. The mean levels of CD4 cells increased by $159 \%$ in 50 patients, which is a major increase; the number of HIV/AIDS pathologies decreased from the 120 baseline to 5; and significant increases were experienced in body weight (12\%), hemoglobin concentration (24\%), and lymphocyte differential count (24\%). IRAB is recommended as part of an HIV/AIDS drug treatment program [16]. Even though not much is known of IRC, its antimalarial properties has been suggested [15]. This study evaluates the effect of IRC a fractionated neem leaf extract on blood glucose levels in alloxan induced diabetic wistar rats.

\section{Materials and Methods}

\section{Area of study}

The study was carried out in the Department of Pharmacology/Therapeutics and Animal house of the College of Medicine, University of Nigeria Enugu Campus.

\section{Sources of drugs}

Fractionated acetone-water neem leaf extract (IRC) was a kind donation from Prof. Udeinya J.I of Rocitus Institute of Research, Enugu Nigeria. Glibenclamide was obtained from a reputable pharmaceutical retail outlet (Annox pharmacy Ltd) Enugu. However the extraction procedure for the preparation of IRC is according to [15].

\section{Aims/Specific objectives of the study}

The aim of this study is to investigate the hypoglycaemic effect of IRC on alloxan induced diabetic wistar rats with specific objectives to find the effect of single dose administration of the extract on blood glucose levels as well as the effect of repeated and prolonged administration of the extract on blood glucose levels in alloxan induced diabetic wistar rats using glibenclamide as a standard hypoglycaemic agent.

\section{Animals used for the study}

Adult male wistar rats of 8-10 weeks old with weighing range $125 \mathrm{~g}-165 \mathrm{~g}$ and mice of either sex weighing between $25-35 \mathrm{~g}$ were used in this study. The animals were obtained from the animal house of the college of Medicine, University of Nigeria Enugu Campus. They were grouped in cages under controlled environmental conditions with the provision of 12 hours light and dark cycles. Commercial rat feed (Top feeds Itd Enugu) was given to the animals throughout the experimental period while water was provided adlibitum. The animals were weighed using an animal balance and separated into groups of six animals each.

\section{Drug preparation}

An electronic weighing balance (mettler toledo $\mathrm{GMBH}, \mathrm{CH}-8606$ ) was used to weigh out the extract (IRC) and glibenclamide used in this study. The drugs (IRC and glibenclamide) were dissolved in phosphate buffered saline (PBS) pH 7.2 before being administered to the test animals based on their weights.

\section{Induction of diabetes in adult wistar rats}

Adult wistar rats with body weight between $125 \mathrm{~g}$ - $165 \mathrm{~g}$ were made diabetic by a single intraperitoneal administration of $150 \mathrm{mg} / \mathrm{kg}$ body weight alloxan monohydrate (Qualikem) dissolved in normal saline 
[17]. The animals were left for 7 days within which blood glucose concentrations were determined in their orbital plexus blood samples using a one touch Accuchek active Glucometer (Roche, USA). Animals with consistent fasting blood glucose greater than $180 \mathrm{mg} / \mathrm{dl}$ were selected for the study. The animals were described "fasted" after 10-12 hours of overnight fast.

\section{Collection of blood and determination of blood glucose}

Blood samples from the adult wistar rats were collected from the retro-orbital plexus of the median canthus vein of the eye using heparinized capillary tubes. Blood glucose was determined by Trinder [18] glucose oxidase method using one Touch ${ }^{\circledR}$ glucometer (Accu-chek active, Roche USA). In this test, glucose oxidase calalyzes the oxidation of glucose to give hydrogen peroxide and gluconic acid. In the presence of the enzyme peroxidase, the hydrogen peroxide is broken down and the oxygen released reacts with 4-aminophenazone and phenol to give a pink colour. The absorbance of the colour produced was measured in a spectrophotometer at 515 nanometer wavelength.

\section{Effect of single oral dose administration of IRC}

Six groups of fasted alloxan induced diabetic adult wistar rats were used. Four groups of six diabetic rats each $(A 1, A 2, A 3, A 4$ ) were given orally $50 \mathrm{mg} / \mathrm{kg}, 500$ $\mathrm{mg} / \mathrm{kg}, 1000 \mathrm{mg} / \mathrm{kg}$ and $2000 \mathrm{mg} / \mathrm{kg}$ body weight of IRC dissolved in $1.5 \mathrm{ml}$ phosphate buffered saline once using a stomach tube. The fifth group (A5; Positive control) was given orally $5 \mathrm{mg} / \mathrm{kg}$ of glibenclamide in $1.5 \mathrm{ml}$ phosphate buffered saline as in groups 1-4. The sixth group (A6; Negative control) was given $1.5 \mathrm{ml}$ phosphate buffered saline only. Blood glucose level were determined at $0 \mathrm{hr}$, (before extract administration) and then after 2 hrs, 4 hrs, 6 hrs; 8 hrs and 24 hrs of administering the extract.

\section{Effect of repeated oral dose administration of IRC}

The effect of repeated oral dose administration of IRC on blood glucose level was carried out in normoglycemic as well as diabetic rats. Four groups of fasted normoglycemic rats were used (B1, B2, B3, B4) with six rats in each group. Groups $B 1$ and $B 2$ were given orally $250 \mathrm{mg} / \mathrm{kg}$ and $100 \mathrm{mg} / \mathrm{kg}$ extract dissolved in $0.7 \mathrm{ml}$ phosphate buffered saline respectively per day for 21 days. Group 3 received $5 \mathrm{mg} / \mathrm{kg}$ body weight of glibenclamide orally per day for 21 days while group B4 was given $0.7 \mathrm{ml}$ of phosphate buffered saline (PBS) per day for 21 days to serve as negative control.

In adult diabetic wistar rats, six groups (C1, C2, C3, $\mathrm{C} 4, \mathrm{C} 5, \mathrm{C} 6)$ containing six diabetic rats each were used. Groups $\mathrm{C} 1$ to $\mathrm{C} 4$ were given orally $5 \mathrm{mg} / \mathrm{kg}, 50 \mathrm{mg} / \mathrm{kg}$, $250 \mathrm{mg} / \mathrm{kg}$ and $500 \mathrm{mg} / \mathrm{kg}$ IRC dissolved in $0.7 \mathrm{ml} \mathrm{PBS}$ per day for 21 days while $C 5$ took $5 \mathrm{mg} / \mathrm{kg}$ body weight of glibenclamide per day for 21 (positive control). Group

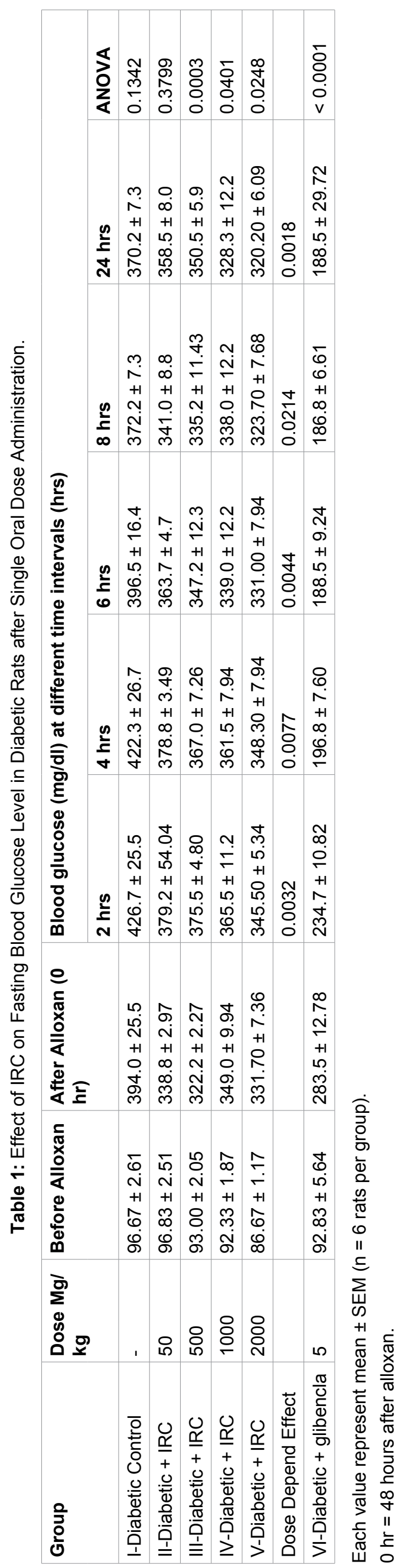


C6 (negative control group) was administered $0.7 \mathrm{ml}$ phosphate buffered saline (PBS; PH 7.2) orally per day for 21 days. Oral administration in each case was done using stomach tube and was continued daily for three weeks. Fasting blood glucose level were determined daily for 7 days and then weekly for two weeks.

\section{Statistical analysis}

The computer software package used was GraphPad prisms. Data were presented as mean plus or minus standard error of mean (SEM). Student t-test and oneway analysis of variance (ANOVA) were used and $P<$ 0.05 was considered significant.

\section{Results}

Effect of single oral dose administration of IRC on fasting blood glucose levels in diabetic adult wistar rats

The mean fasting blood glucose levels at various time intervals after a single oral administration of IRC in diabetic adult wistar rats are shown in Table 1. Oneway analysis of variance showed statistical significant differences in fasting blood glucose levels with duration of exposure in groups III ( $P=0.0003)$, IV $(P=0.0401)$, $V(P=0.0248)$ and group VI $(p<0.0001)$. There was a statistical significant change $(P<0.0001)$ in fasting blood glucose levels in the glibenclamide treated group at all time intervals when compared to the negative control.

After a single oral administration of varying doses of the extract, a dose dependent significant change in fasting blood glucose levels were observed at 2 hours ( $P$ $=0.0032), 4$ hours $(P=0.0077), 6$ hours $(P=0.0044), 8$ hours $(P=0.0214)$ and 24 hours $(P=0.0018)$.

The percentage reduction in fasting blood glucose levels after single oral administration of varying doses of IRC in adult diabetic wistar rats is shown in Figure 1. A dose dependent percentage reduction in fasting blood glucose level was observed with $500 \mathrm{mg} / \mathrm{kg}, 1000 \mathrm{mg} /$

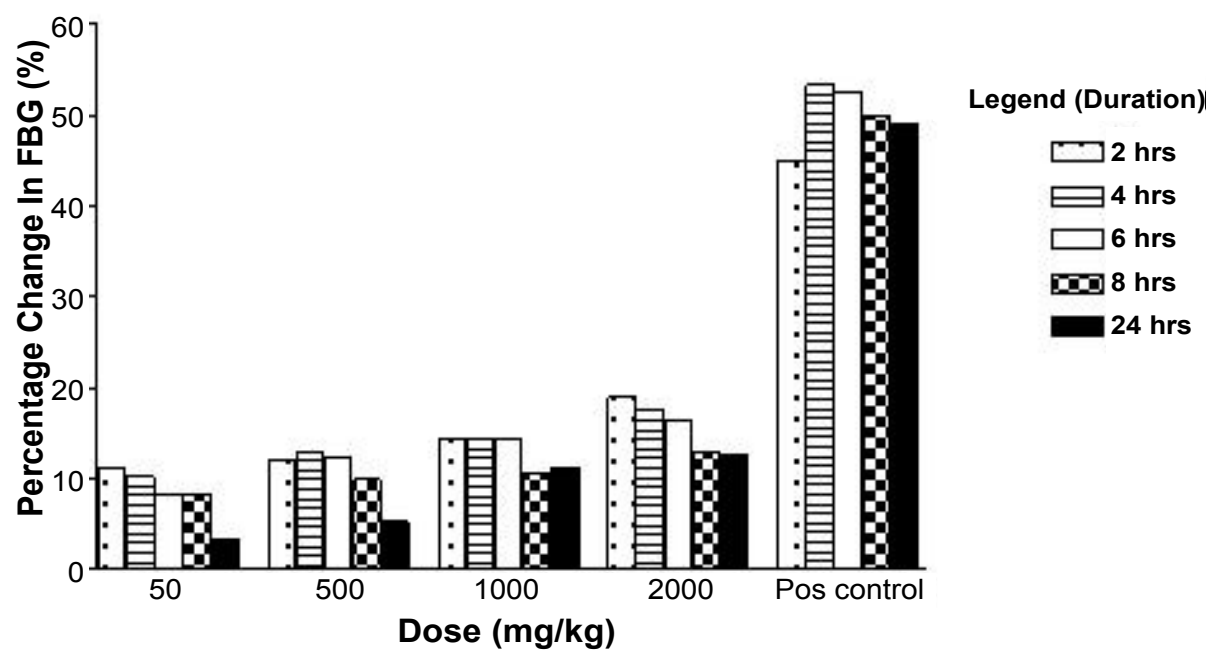

Figure 1: Effect of IRC on FBG level in diabetic rats after single oral dose administration.

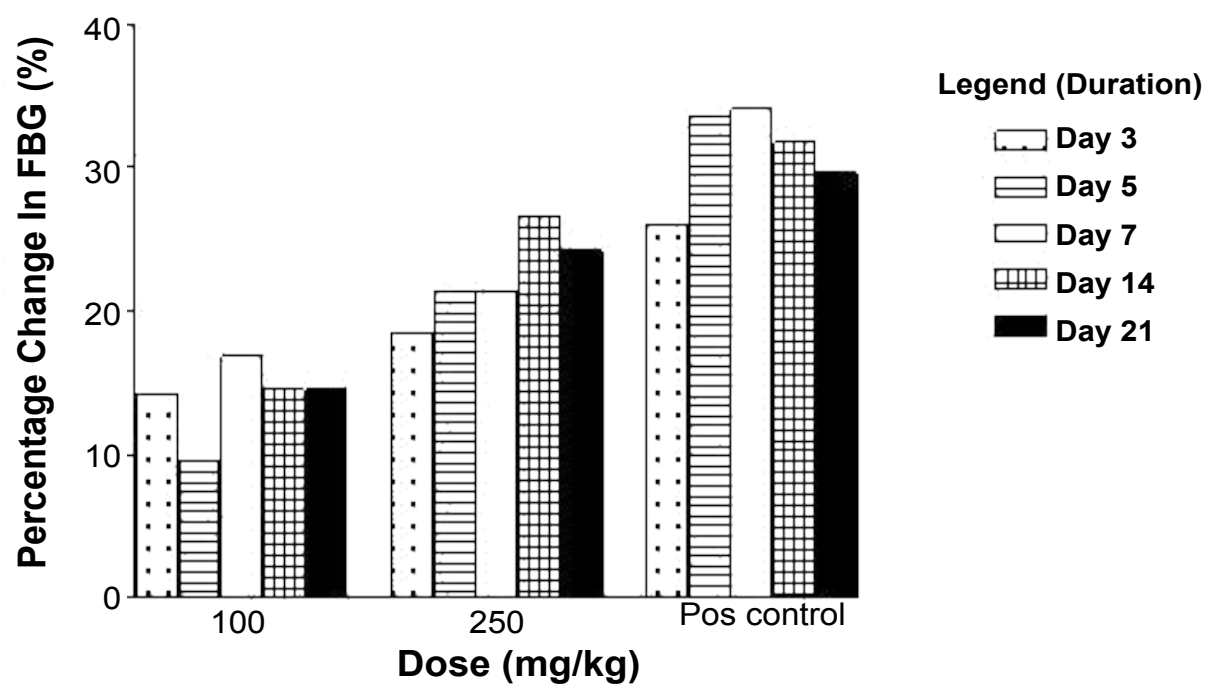

Figure 2: Effect of IRC on FBG level in normoglycaemic rats after repeated dose administration. 
$\mathrm{kg}$ and $2000 \mathrm{mg} / \mathrm{kg}$ single doses of IRC administered to the diabetic rat. Highest percentage reduction in fasting blood glucose occurred 4 hours after extract administration in most doses with reduction of $10.3 \%$ (50 mg/kg IRC) 12.78\% (500 mg/kg IRC), 14.40\% (1000 $\mathrm{mg} / \mathrm{kg}$ IRC) and $17.50 \%$ (2000 mg/kg IRC) compared to $53.40 \%$ of glibenclamide at the same time (Figure 1). Percentage reduction in fasting blood glucose levels were more significantly $(P<0.001$ for each) in the glibenclamide treated group at all time intervals when compared to the test groups.

\section{Effect of repeated (multiple) dose administration of IRC on fasting blood glucose levels in non- diabetic (normoglycaemic) adult wistar rats}

The mean fasting blood glucose levels at various time intervals after repeated (multiple) oral administration of $100 \mathrm{mg} / \mathrm{kg}$ and $250 \mathrm{mg} / \mathrm{kg}$ of IRC daily for 21 days in different groups of normoglycaemic adult wistar rats are shown in Table 2.

One-way analysis of variance showed a statistical significant difference in fasting blood glucose levels with duration of exposure in groups II ( $P=0.0032)$, III ( $P=$ $0.0020)$ and group IV ( $P=0.0001)$ (Table 2$)$. There was a statistical significant difference $(P<0.0001)$ in fasting blood glucose levels in the glibenclamide treated groups at all time intervals when compared to the negative control.

There was dose dependent significant difference in fasting blood glucose levels observed after repeated administration of $100 \mathrm{mg} / \mathrm{kg}$ and $250 \mathrm{mg} / \mathrm{kg}$ extract daily for 21 days on day $1(P=0.0405)$, day $3(P=0.0018)$, day $5(P=0.0004)$, day $7(P=0.0005)$, day $14(P<0.0001)$ and on day $21(P=0.0464)$.

The percentage reduction in fasting blood glucose level after daily oral administration of varying doses of IRC in adult normoglycaemic wistar rats are shown in Figure 2. There were dose dependent percentage reductions in fasting blood glucose level observed after administering $100 \mathrm{mg} / \mathrm{kg}$ and $250 \mathrm{mg} / \mathrm{kg}$ IRC daily for 21 days in the normoglycaemic rats (Figure 2). The percentage reduction in fasting blood glucose level after daily treatment for 7 days were $16.80 \%$ (100 mg/kg IRC) and $21.40 \%(250 \mathrm{mg} / \mathrm{kg} \mathrm{IRC})$ compared to $34.10 \%$ of glibenclamide $5 \mathrm{mg} / \mathrm{kg}$ at the same time. Percentage reductions in fasting blood glucose levels were more significant $(P<0.0001$ for each) in the glibenclamide treated group at all time intervals when compared to the test groups.

Effect of repeated (multiple) dose administration of IRC on fasting blood glucose levels in diabetic adult wistar rats

The mean fasting blood glucose levels at various time intervals after repeated (multiple) oral administration of

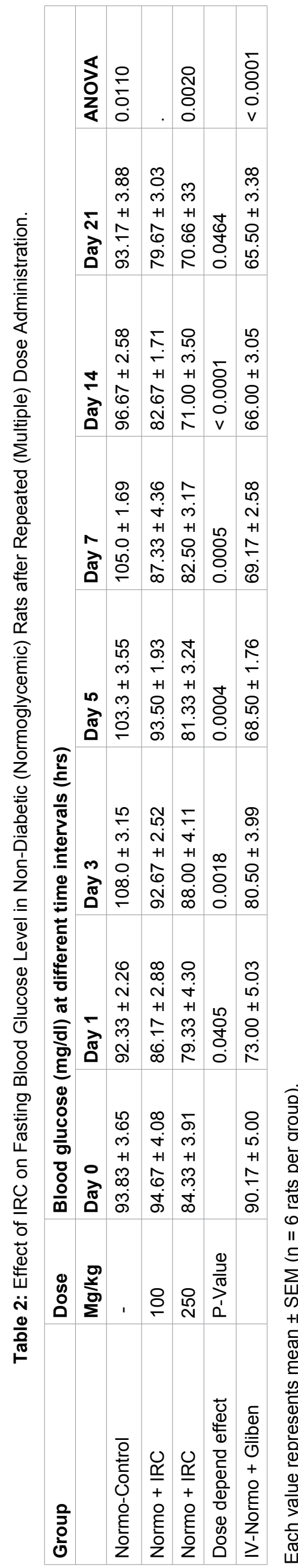


IRC daily for 21 days in different groups of diabetic adult wistar rats are presented in Table 3. One way analysis of variance showed a significant difference in fasting blood glucose levels with duration of exposure in groups III ( $p$ $<0.0001)$, IV $(P<0.0001), V(P<0.0001)$ and group VI $(P<0.0001)$.

A statistical significant dose dependent decrease in fasting blood glucose levels were observed on day 1 ( $P$ $=0.0184)$, day $3(P=0.0006)$ day $5(P<0.0001)$, day $7(P$ $<0.0001)$, day $14(P<0.0001)$ and day $21(P<0.0001)$.

The percentage reduction in fasting blood glucose level after daily oral administration of varying doses of the extract in diabetic adult wistar rats is shown in Figure 3. The dose dependent Percentage reductions in fasting blood glucose level were observed with $50 \mathrm{mg} /$ $\mathrm{kg}, 250 \mathrm{mg} / \mathrm{kg}$ and $500 \mathrm{mg} / \mathrm{kg}$ IRC administered daily for 21 days in the diabetic adult wistar rats.

Maximal percentage reduction in fasting blood glucose after daily treatment for seven days with the varying IRC doses are $33.20 \%$ (50 mg/ $\mathrm{kg}$ ), 49.00\% (250 $\mathrm{mg} / \mathrm{kg}), 55.10 \%(500 \mathrm{mg} / \mathrm{kg}$ ) compared to $58.20 \%$ produced by $5 \mathrm{mg} / \mathrm{kg}$ daily doses of glibenclamide at the same time interval. Percentage reduction in fasting blood glucose levels for the glibenclamide treated group were $49.0 \%$ (day 3 ), $53.0 \%$ (day 5) $58.2 \%$ (day 7 ), $38.4 \%$ (day14) and 33.0\% (day 21) and were higher compared to the reductions produced by the various doses of the test groups.

There was a drop in fasting blood glucose levels observed after treatment for 14 to 21 days with the various doses of IRC and glibenclamide (Figure 3).

\section{Discussion}

This study was carried out to investigate the hypoglycaemic effects of fractionated neem leaf extract IRC when given orally to alloxan-induced diabetic adult wistar rats. Diabetes mellitus was experimentally induced by intraperitoneal injection of alloxan at a single dose of $150 \mathrm{mg} / \mathrm{kg}$ body weight which is in line with the study of Ragavan and Krishnakumari [17]. It had been observed in this study that the intraperitoneal injection of alloxan monohydrate at a single dose of $150 \mathrm{mg} /$ $\mathrm{kg}$ of body weight elevated fasting blood glucose level more than one hundred percent compared to normal fasting blood glucose level in adult wistar rats. This is in accordance with previous report of adult rats treated with alloxan which exhibited increased fasting blood glucose two to five days after administration [19-21]. This rise in blood glucose level might be due to partial or complete destruction of the $\beta$-cells of the pancreatic islet cells of the adult rats. Alloxan is a beta cell cytotoxin mediating its action by generating reactive oxygen species that cause rapid destruction of $\beta$-Cells resulting in a hyperglycaemic state [22].

In this study the evaluation of the hypoglycaemic 


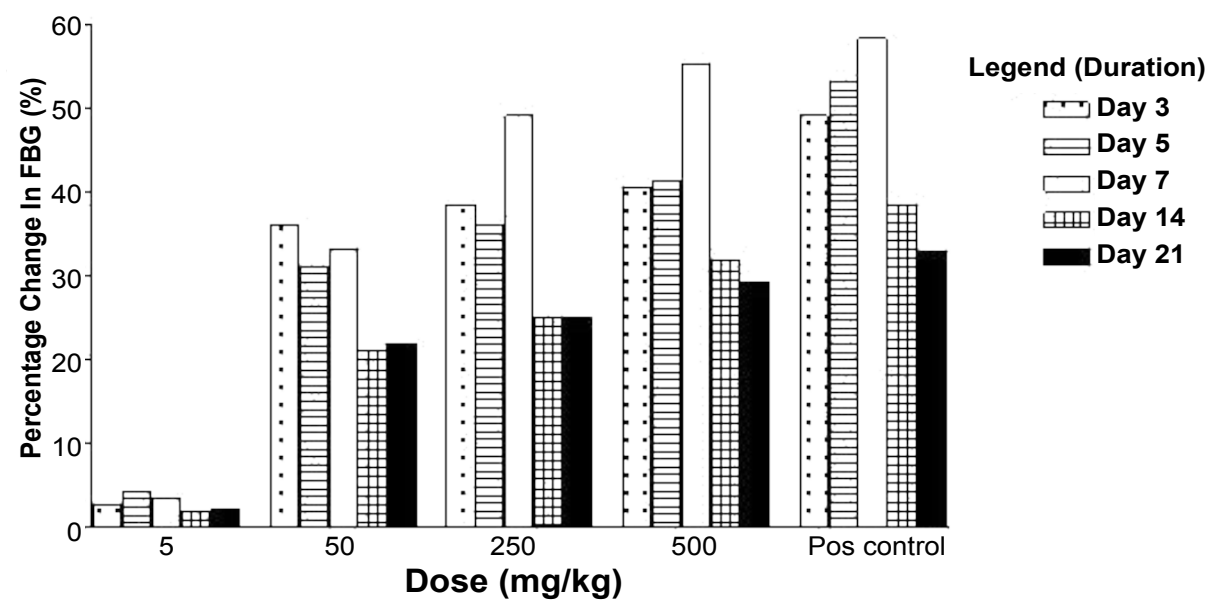

Figure 3: Effect of IRC on FBG level in diabetic rats after repeated dose administration.

activity of IRC in normal and alloxan- induced diabetic wistar rats gave significant results. Single doses of the extract $(500 \mathrm{mg} / \mathrm{kg}, 1000 \mathrm{mg} / \mathrm{kg}$ and $2000 \mathrm{mg} /$ $\mathrm{kg}$ ) in diabetic wistar rats produced dose dependent percentage reduction in fasting blood glucose level. The percentage reduction was maximal after 4 hours of administration and were $13.10 \%(500 \mathrm{mg} / \mathrm{kg}), 14.40 \%$ $(1000 \mathrm{mg} / \mathrm{kg})$ and $17.50 \%(2000 \mathrm{mg} / \mathrm{kg})$ respectively. Glibenclamide $(5 \mathrm{mg} / \mathrm{kg}$ ) single dose produced a percentage reduction in fasting blood glucose level of $53.40 \%$ at the same hour. Results from previous studies indicated a 22.4 and 36.91 percentage reductions in blood glucose levels at 6 hours after single dose administration of $250 \mathrm{mg} / \mathrm{kg}$ and $1000 \mathrm{mg} / \mathrm{kg}$ body weight of aqueous neem leaf extract in alloxan induced diabetic rats $[14,23]$ and an 18 percent reduction after $24 \mathrm{hrs}$ treatment with $250 \mathrm{mg} / \mathrm{kg}$ single dose [14]. These results are higher than those obtained from this study.

A dose dependent percentage reduction in fasting blood glucose levels in the diabetic and non-diabetic wistar rats was observed with IRC in the repeated dose effect study. The percentage reduction in fasting blood glucose level on diabetic induced wister rats after daily treatment for 7 days were $(3.4 \%) 5 \mathrm{mg} / \mathrm{kg}$, (33.2\%) $50 \mathrm{mg} /$ $\mathrm{kg},(49.0 \%) 250 \mathrm{mg} / \mathrm{kg},(55.1 \%) 500 \mathrm{mg} / \mathrm{kg}$ and $(58.1 \%)$ $5 \mathrm{mg} / \mathrm{kg}$ of Glibenclamide. Also, the daily treatments percentage reduction for 14 days were $(2.0 \%) 5 \mathrm{mg} /$ $\mathrm{kg},(21.0 \%) 50 \mathrm{mg} / \mathrm{kg},(25.4 \%) 250 \mathrm{mg} / \mathrm{kg},(31.7 \%) 500$ $\mathrm{mg} / \mathrm{kg}$ and (38.4\%) $5 \mathrm{mg} / \mathrm{kg}$ for Glibenclamide while the daily treatments percentage reduction for 21 days were $(2.2 .0 \%) 5 \mathrm{mg} / \mathrm{kg}$, (22.0\%) $50 \mathrm{mg} / \mathrm{kg},(25.04 \%)$ $250 \mathrm{mg} / \mathrm{kg}$, (29.3\%) $500 \mathrm{mg} / \mathrm{kg}$ and (33.0\%) $5 \mathrm{mg} / \mathrm{kg}$ of Glibenclamide. These findings were also comparable with earlier works reported by Murty, et al. [24] in dogs and Khosla, et al. [25] in diabetic rabbits which indicated a $13.53 \%(500 \mathrm{mg} / \mathrm{kg})$ reduction in fasting blood glucose levels after one week of treatment. Also, Shravan, et al. [14] in diabetic rats reported a $56.54 \%(250 \mathrm{mg} / \mathrm{kg})$ reduction within the same time interval.

In addition, a dose dependent Percentage reductions in fasting blood glucose level were observed in nondiabetic (normoglycaemic) rats with IRC repeated doses as follows: $100 \mathrm{mg} / \mathrm{kg}(16.8 \%), 250 \mathrm{mg} / \mathrm{kg}(21.4 \%)$ and for glibenclamide $5 \mathrm{mg} / \mathrm{kg}$ (34.1\%) after 7days of treatment, and (14.5\%) $100 \mathrm{mg} / \mathrm{kg}$, (26.6\%) $250 \mathrm{mg} / \mathrm{kg}$ IRC and (31.72\%) $5 \mathrm{mg} / \mathrm{kg}$ glibenclamide after treatment for 14 days. Also, the daily treatments percentage reduction for 21 days were $(14.5 \%) 100 \mathrm{mg} / \mathrm{kg},(24.16 \%)$ $250 \mathrm{mg} / \mathrm{kg} \mathrm{IRC}$ and $(29.6 \%) 5 \mathrm{mg} / \mathrm{kg}$ glibenclamide. A higher percentage reduction in fasting blood glucose level was observed in the diabetic rats compared to the non-diabetic (normoglycaemic) rats. In both groups the percentage reduction in blood glucose was less in the treatment groups compared to the glibenclamide treated groups. There was a drop in fasting blood glucose levels observed after treatment for 14 to 21 days with the various doses of IRC and glibenclamide. In general, this may be as a result of the diminishing effect of alloxan with time.

Alloxan-induced diabetic state may result in a complete or partial loss of pancreatic B-cell activity producing severe or moderate diabetes [26]. The severe diabetes produced by alloxan results in blood glucose levels equivalent to a total pancreatomy while the moderate diabetes may mimick the type II diabetic model in which there is a partial destruction of the $\beta$-cells. In this study where there may be a complete or partial loss of pancreatic $\beta$-cell activity due to alloxan effect, IRC caused a significant reduction in blood glucose level in both normoglycaemic and diabetic adult rats. This indicates that the extract may contain bioactive compounds which probably act by increasing insulin release or by enhancing the uptake and utilization of glucose peripherally.

Previous studies on the neem medicinal plant showed that its crude leaf extract contain bioactive compounds like azadirachtin, meliacin, nimbidin and other glycoside constituents which may be responsible for its hypoglycaemic activity $[27,28]$. Nimbidin was reported [29] to significantly delay the peak rise in 
blood glucose level in diabetic rats lacking insulin. Other possible mechanisms in improving glucose homeostasis by IRC which may be involved here include the inhibition of intestinal glucose absorption and the reduction of the effect of glutathione. In diabetes mellitus, there is a deficiency or insufficiency of insulin secretion or insulin resistance which usually cause a decrease in body weight and increase in food and water intake [30].

The results of this study showed that IRC reduced blood glucose levels in normal and alloxan-induced diabetic wistar rats when given orally. Its hypoglycaemic effect was more pronounced in the diabetic rats than the non-diabetic (normoglycaemic) adult rats.

\section{Conflict of Interest}

The authors declare no conflict of interest.

\section{Acknowledgement}

The authors are grateful to the animal house unit staff of the College of Medicine University of Nigeria Enugu Campus for their technical assistance.

\section{References}

1. Ebe UT (2004) Traditional medicine. Journal of Traditional Medicare 4: 66-68.

2. Tsay HS, Agrawal DC (2005) Tissue culture technology of Chinese medicinal plant resources in Taiwan and their sustainable utilization. Int J App Sci Eng 3: 215-223.

3. Sofowora A (1984) Medicinal Plants and Traditional Medicine in Africa. Johnwiley, New York, 256-257.

4. National Research Council (1992) Neem: A tree for solving global problems. National academic Press, Washington, DC, USA.

5. Jacobson M (1990) Review of neem research in the United States. USAA-ARS, Beltsville, USA, 40-44.

6. Verkerk RHJ, Wright DJ (1993) Biological activity of neem seed kernel extract and synthetic azadirachtin against larvae of Plutella xylostella L. Pesticide Science 37: 83-91.

7. Sharma P, Tomar L, Bachwani M, Bansal V (2011) Review on neem (Azadirechta indica): Thousand problem one solution. Int Res J Pharmacy 2: 97-102.

8. Djenontin Tindo S, Amusant N, Dangou J, Wotto DV, Avlessi F, et al. (2012) Screening of repellent, termiticidal and preventive activities on wood, of Azadirachta indica and Carapa procera (Meliaceae) seeds oils. J Biological Sci 1: 25-29.

9. Mondal D, Mondal T (2012) A Review on efficacy of Azadirachta indica A. Juss based biopesticides: An Indian perspective. Res J Recent Sci 1: 94-99.

10. Kraus W (1995) The neem tree: Source of unique national products for integrated pest management, medicine, industry and purposes. VCH Publishers, Inc Weinheim, Germany, 35-88.

11. Charles V, Charles SX (1992) The use and efficacy of Azadirachta indica ADR (neem) and Curcuma longa (turmeric) in scabies. A pilot study. Trop Geogr Med 44: 178-181.

12. Parotta J A (2001) Healing plants of Peninsular India. CABI Publishing, New York, 495-496.

13. Ross I A (2001) Medicinal plants of the world: Chemical constituents, traditional and modern medicinal uses. Totowa, New Jersey, USA, 2: 81-85.

14. Shravan K D, Ramakrishna R, Santhosh K M, Kannappan $N$ (2011) In vivo antidiabetic evaluation of neem leaf extract in alloxan induced rats. Journal of Applied Pharmaceutical Science 1: 100-105.

15. Udeinya I J (1993) Antimalarial activity of Nigerian neem leaves. Transactions of the Royal Society of Tropical Medicine and Hygiene 87: 471-472.

16. Mbah A U, Udeinya I J, Shu EN, Chijioke CP, Nubila T, et al. (2007) Fractionated neem leaf extract is safe and increases CD4+ cell levels in HIVIAIDS patients. Am J Ther 14: $369-374$

17. Ragavan B, Krishnakumari S (2006) Hypoglycaemic and hypolipidemic activities of terminalia arjuna stem bark in alloxan induced diabetic rats. J Natural Remedies 6: 124130.

18. Trinder $P$ (1967) Determination of blood glucose using 5-aminophenazone as oxygen acceptor. J Clin Pathol 22: 246-248.

19. Yanardag R, Colak H (1998) Effect of beta vulgaris varcicla on blood glucose level in normal and alloxan induced diabetic rabbit. J Ethnopharm 4: 309-311.

20. Baltel M L, Yuen VG, Verma S, NcNeil J H (1999) Other models of type I diabetes, in experimental models of diabetes (Mc- Neil J. H ed) CRC press Inc 219-226.

21. Nahar L, Ripa FA, Hasanat A, Zulfiker MD, Rokonuzman $M D$, et al. (2010) Comparative study of antidiabetic effect of Abroma augusta and Syzygium cumini on alloxan induced diabetic rat. Agri Bio J North America 10: 1267-1272.

22. Elsner M, Gurgul-Convey E, Lenzen S (2006) Relative importance of cellular uptake and reactive oxygen species for the toxicity of alloxan and dialuric acid to insulin producing cells. Free Radic Biol Med 41: 825-834.

23. Rasheda A, Mahabub U Z, Saidur R, Afronza K, Abdullah $M$, et al. (2013) Comparative studies on anti-diabetic effect with photochemical screening of Azadirachta indica and Andrographis paniculata. Journal of pharmacy and Biological sciences 5: 122-128.

24. Murty K S, Rao N, Rao D K, Murty B G (1978) A preliminary study on hypoglycaemic and antihyperglycaemic effects of Azadirachta indica. Indian J Pharmacol 10: 247-250.

25. Khosla P, Sangedla B, Sing J, Seth S, Srivastava RK (2000) A study of hypoglycaemic effects of Azadirachta indica in normal and alloxan diabetic rabbits. Indian $\mathrm{J}$ Physiol Pharmacol 44: 69-74.

26. Huralikuppi J C (1991) Ant-diabetic effect of Nelumbo nucifera extract. Phytother Res 5: 217-223.

27. Chattopadhyay RR (1999) Possible mechanisms of antihyperglycaemic effects of Azadirachta indica leaf extract. J Ethnopharmacol 67: 373-376.

28. Iman H, Hussain A, Ajid A (2012) Review of geographical distribution of Azadirachla indica and its medicinal properties. International Research Journal of Biol Sciences 1: 50-69.

29. Ajik-Kar C, Choundhary BK, Banddhyopadhyay NG (2003) Comparative evaluation of hypoglycaemic activity of some Indian medicinal plants in alloxan diabetic rats. $J$ Ethnopharmacol 84: 105-108.

30. Perez-Gutierrez RM, Damian G M (2012) Meliacinolin a potent $\alpha$-glucosidase and $\alpha$-amylase inhibitor isolated from Azadirachta indica leaves and in vivo anti-diabetic property in streptozotocin nicotinamide induced type2 diabetes in mice. Biol Pham Bull 35: 1516-1524. 